\title{
TÓTH Kornél
}

\section{AZ ÉRTÉKALAPÚ SZÁMVITEL SZEREPE A BESZÁMOLÓBAN ÉS A SZABÁLYOZÁS}

Az elmúlt néhány évtizedben a vállalatok számviteli információs rendszerei jelentốs változáson mentek át, és ennek következtében egyre nagyobb szerepet kapott az egyes mérlegtételek valós értéken történố megjelenítése. Ugyanakkor a globalizáció kihívásokat is teremtett a számvitelben, amelyek közül elsôsorban a pénzügyi instrumentumok valós értékének megbízható mérése jelent problémát. Noha az új tranzakciótípusok hozzájárulnak a vállalatok megnövekedett kockázatainak kezeléséhez, a kedvezótlen világgazdasági környezet a pénzpiaci árak volatilitását és instabilitását eredményezte. Az értékalapú számvitel lehetôséget teremthet a pénzügyi jelentések hasznosságának növelésére, de ennek érdekében a szabályozásban is a következetességre és egyszerúsítésre kell helyezni a hangsúlyt. A dolgozat bemutatja az értékelés és az értékalapú számvitel feladatait, közgazdasági hátterét, kapcsolatát a beszámolóval, valamint annak részeként kitér a valós értékelés szabályozására és annak a pénzügyi válság miatti változásaira.

Kulcsszavak: számviteli beszámoló, pénzügyi instrumentumok, nemzetközi számviteli standardok, valós értékelés

A vállalkozások számviteli rendszerei nagy mennyiségú adatot kezelnek, amelyek összevontan a gazdálkodó szervezetek pénzügyi kimutatásaiban jelennek meg. A gyorsan változó piaci környezetben ezen adatoknak releváns információkat kell közvetíteniük a jövedelmi, pénzügyi helyzetről a megbízható, valós összkép érdekében. A vállalati teljesítmény értékelése alapvetôen az idôszakonként kiadott pénzügyi jelentéseken alapul, ezek a számviteli elvek szerint készített pénzügyi kimutatások a management döntéseinek hatását tükrözik. Az elmúlt néhány évtized számviteli vagyonfelfogását és súlypontjait vizsgálva megállapítható, hogy a kiszámíthatatlanabb, bizonytalanabb versenyhelyzet következtében bizonyos mérlegtételek vonatkozásában a bekerülési értékre alapozott értékelés mellett megjelent egyes eszközök - mint például a pénzügyi instrumentumok valós értéken történő értékelése. Ezen újszerú értékelési megközelítés elônyei mellett alkalmazásának fố problémája, hogy a pénzügyi kimutatások egyes sorainak értéke hogyan mérhetố megbízhatóan, különösen azon eszközök esetében, amelyeknek nincs vagy megszűnt az aktív piaca, illetve a piac illikvid. Ilyenkor a számviteli információk felhasználóinak kell megbecsülniük a beszámolókból nyert adatok hasznosságát, illetve azok minőségi jellemzőit.

\section{Az értékelés feladata és}

\section{kapcsolata a beszámolóval}

A számvitel és pénzügyi beszámolás alapvetô célja, hogy megbízható, valós és teljes körú képet adjon a vállalkozás vagyoni-pénzügyi helyzetéról, illetve annak jövedelemtermelő képességéról. A számvitel ennek érdekében alapelveket fogalmaz meg, ugyanakkor a vagyon, valamint annak forrásának bemutatása során felmerül a kérdés, hogy ezeket az elemeket milyen értéken szerepeltessük a mérlegben. A beszámolónak megbízható és valós összképet kell közvetítenie, a mérlegtételek értékének ugyanezen feltételeknek kell megfelelnie, mivel a vállalkozás jövedelemtermelő képességéról alkotott képet is ez határozza meg. Az egyik legfontosabb számviteli alapelv a vállalkozás folytatásának elve, amelynek lényege, hogy a vállalkozás belátható időn belül nem hagy fel tevékenységével. Ez az alapelv újabb elveket generál, mint például az összemérés elve, az idóbeli elhatárolás elve, vagy az óvatosság és a valódiság elve. Ez utóbbi két számviteli elv határozza meg leginkább az alkalmazott értékelési eljárásokat és módszereket, mivel ezen elvekkel sok mérlegtétel összefügg, például immateriális javak, tárgyi eszközök, kötelezettségek. A magyar számvitelben a konkrét értékeket e két elv aránya határozza meg (Korom et al., 2005). Az általános számviteli be- 
számolási feladatok mellett a vagyon- és üzletértékelési tevékenységek az alábbi célokat szolgálják:

- a vagyonmérleg egyes elemeinek értékelése, a cégérték becslése,

- az átalakulás elókészítése, az apportlista egyes elemeinek tételes értékelése,

- az eszközök, vagyontárgyak valós piaci értékének megállapítása értékelési tartalék meghatározása céljából, valamint az eszközök élettartamának és maradványértékének megállapítása,

- hitelbiztosíték finanszírozása - fedezeti érték megállapítása,

- biztosítási érték, újraelőállítási érték megállapítása,

- értékesítés vagy vásárlás - eszközök, vagyontárgyak valós piaci értékének megállapítása,

- felszámolás - eszközök szabályos felszámolási értékének megállapítása,

- hitelból finanszírozott kivásárlás,

- cégvásárlás, befektetések értékének megállapítása, immateriális eszközök értékelése.

Számviteli megközelítésben vagyonnak tekinthetjük azon jelenségeket, amelyek egy vállalkozás számára adott idôpontban gazdasági tartalommal bírnak és értékelhetők. A kérdés az, hogy mikor tekinthető egy jelenség vagyonelemnek, és milyen értéket képvisel az adott jelenség. E kérdés megválaszolása különösen fontos szerepet kap a pénzügyi piacok és eszközök fejlődésével, és ezt az is bonyolítja, hogy a különféle vagyonelemek értékelése nem végezhetô el egyszerúen képlettel vagy számítással. A megbízható értékelések megfelelő tájékozottságot igényelnek, amelyeknek a múlt ismeretét, a jelen megértését és reális jövốbeni elvárásokat kell tükrözniük. E célok érdekében létrejött a Nemzetközi Értékelési Standard Bizottság (IVSC ${ }^{1}$ ), feladata, hogy olyan standardokat alkosson, amelyek a piaci szereplốk számára az IAS és IFRS-beszámolási rendszerek ${ }^{2}$ értelmezését megkönnyítik. A nemzetközi értékelési standardok $\left(\right.$ IVS $^{3}$ ) és az IAS (IFRS)-ek kapcsolatában megállapítható, hogy a modern számviteli rendszerek információtartalmát nem a kormányzati adópolitika, sokkal inkább a piaci szereplók információigénye befolyásolja. ${ }^{4}$ Mint ismeretes, a számvitelnek alapvetóen a vagyon és a vagyonváltozás követése és megjelenítése a feladata. A vállalkozások irányításához, illetve a piaci környezet változásaihoz való rugalmas alkalmazkodáshoz ismerni kell a vagyonváltozások hatásait, azaz a jelenségeket tulajdonságjellemzóik alapján tartalmilag azonosítani és különbözó szempontok szerint értékelni kell. Mivel a piaci szereplő́k pedig elsősorban a befektetésük piaci értékére kíváncsiak, a nemzetközi számviteli standardokban és a magyar számviteli szabályokban is szerepet kapott a piaci érték meghatározásának igénye, amelynek Havas (2002) és Jakab et al. (2006) alapján a leggyakoribb területei az alábbiak:

- az immateriális javak és tárgyi eszközök terven felüli értékcsökkenése,

- a goodwill értékelése,

- értékelési tartalék és értékhelyesbítések megítélése,

- az egyes pénzügyi instrumentumok piaci értéke, a részesedések értékelése,

- az aktualizált értéken történó konszolidálás,

- a befektetési célú ingatlanok értékelése,

- a transzferárak, kapcsolt ügyletek megítélése, adózás a piaci árak után,

- a felszámolási mérlegek értékelése,

- az apport hitelesítése,

- csereügyletek, cégfelvásárlások értékelése.

\section{A valós értékelés kialakulása és kihívásai}

Az elmúlt néhány évtized társadalmi-gazdasági változásai, a multinacionális vállalatok megjelenése, az informatikai eszközök gyors fejlődése, a pénzügyi múveletek körének bővülése és a globalizáció újabb és újabb kihívásokat támasztanak a számvitelben is (Baricz, 2008; 1994). A pénzügyi instrumentumok, illetve származékos ügyletek térnyerését a nemzetközi kereskedelem növekvő jelentősége, az export-import tevékenység és a külföldi befektetések ösztönözték, és mindez magával hozta a kockázatok és a bizonytalanság növekedését is. ${ }^{5}$ A pénzpiacok, pénzügyi tranzakciók és az azt bonyolító, ellátó intézmények fejlődése egyértelmúen az elmúlt évtizedek technikai-technológiai fejlődésének következménye. A közgazdasági irodalom szerint a pénz, a pénzügyi közvetítés és a pénzpiacok, illetve a velük kapcsolatos tranzakciók és instrumentumok a gazdasági tevékenység információhiányá ból, bizonytalanságából, illetve azok egyenlőtlen megoszlásából származó problémáit oldanák meg. Ez összefügg a tranzakciós költségek csökkentésével, mivel azok alapvetően a jószágokra, vagyonelemekre, üzleti lehetőségekre vonatkozó információk megszerzése, illetve ezek költségessége miatt keletkeznek. A piacok általában, így a pénzügyi piacok sem múködnek költségmentesen, és a piaci lehetőségek információinak megszerzéséhez is erőforrásokra van szükség. Az információs és tranzakciós költségek miatt tehát egy optimalizációs problémát kell megoldani, ehhez optimális eljárásokat, intézményeket kell létrehozni. Optimális megoldásnak tekinthetjük azt, amely a minimumra csökkenti a bizonytalanságot és a tranzakciós költségeket. Napjaink globális piacain hatalmas vagyonok mozoghatnak, alakulhatnak át egyik formá- 
ból - valutanemból stb. - a másikba a tranzakciók értékéhez képest csekély költségek mellett (Pete, 1999). A vállalati gyakorlatban tehát a piacok fejlődése nagyban hozzájárult azok megnövekedett kockázatainak kezeléséhez. Ennek a leggyakoribb eszközei a származékos ügyletek (derivatívok): futuresek, forwardok, swapok, opciók, amelyek fó célja, hogy bizonyos eredményt érjünk el, amikor egy értékpapír, index, kamatráta, áru, vagy más pénzügyi eszköz ára változik. ${ }^{6}$ Származékos ügyletnek tekinthetjük az árukra és a pénzügyi eszközökre vonatkozó elszámolási ügyleteket, valamint a pénzügyi eszközökre vonatkozó leszállítási ügyleteket. Ezek pénzügyi rendezésére egy előre meghatározott jövőbeni idôpontban kerül sor. Értékük pedig egy meghatározott kamatláb, hitelviszonyt megtestesító értékpapír, illetve tulajdoni részesedést jelentő befektetés árfolyama, áru vagy pénzügyi eszköz ára, devizaárfolyam, árindex, kamatindex, hitelmérték vagy hitelindex, illetve egyéb hasonló tényezók függvényében változik. Közös jellemzőjük, hogy a lejárati idő alatt megbecsülhetô a várható eredményük, ezért értékelhetôk, és a valós értéken történő értékelés tárgyát képezik. Wilson - Stanwick (1995) szerint a pénzügyi eszközök számviteli bemutathatóságát az is negatívan befolyásolja, hogy azok minimális kezdeti befektetést igényelnek, ezek az ügyletkötéssel kapcsolatban felmerült költségeket foglalják magukban, és a származékos ügylet bekerülési értékének részét képezik (például ügynöki jutalék, bizományi díj, opciós díj stb.). Az is elófordul, hogy egyáltalán nem kapcsolódik hozzájuk ilyen költség, és a bekerülési értékük nulla. Céljuk szerint lehetnek: kereskedési célú és fedezeti célú ügyletek. A kereskedési (nem fedezeti) ügyletek célja a rövid távú árfolyamnyereség elérése a haszonszerzés, a vagyon gyarapítása érdekében. A fedezeti ügylet célja pedig valamely meglévố alapügylet (fedezett ügylet), illetve az abban bekövetkező változás miatti várható veszteség lefedése, ellensúlyozása a fedezeti ügyletból várható nyereséggel, vagy az alapügylet várható pénzáramlásában bekövetkező változás ellensúlyozása, fedezése. Az ár- és árfolyamváltozásból adódó veszteség fedezetére kötött ügyletek lehetnek piaci érték (valós érték) fedezeti ügyletek, valamint külföldi gazdálkodó szervezetben lévő nettó befektetés fedezeti ügyletek, míg az alapügylet pénzáramlásában bekövetkező változást fedező ügyletek a cash flow-fedezeti ügyletek (Nagy, 2004a).

A számvitel alapproblémája ezen eszközökkel kapcsolatban is az, hogy mit tekintsünk vagyonelemnek, illetve az, hogy a különféle értékelési lehetôségek alapján e jelenségekhez többféle ár vagy érték rendelhető. Landsman (2006) alapján megállapítható, hogy az elmúlt idôszakokban tendenciává vált a pénzügyi instru- mentumok valós értékelése, bár számos ország számviteli rendszere a kevert értékelési modellt (részben múltbeli, részben valós értékelés) alkalmazza, az USA és a nemzetközi standardalkotó testületek (FASB ${ }^{7}$, illetve $\mathrm{IASB}^{8}$ ) mellett az amerikai tózsdefelügyelet $\left(\mathrm{SEC}^{9}\right)$ is ezt támogatja. Bár sokféle meghatározás fordul elő, általában a pénzügyi eszközök valós értéke a rendelkezésre álló információk szerinti piaci érték, például tôzsdei ár. Ugyanakkor ez lehet két fél között kialakított ár, amely a tôzsdén kívüli piacon kialakult, a piaci tendenciákat tükröző érték, illetve más hasonló instrumentum piaci értéke alapján számított érték, vagy valamilyen értékelési eljárással megállapított, piaci árat közelítő érték. ${ }^{11}$ A fentebb említett tendenciák eddig ismeretlen pénzügyi termékek mérlegbe való felvételét is jelenthetik, bár a nehezen mérhetố és értékelhetố jelenségeket csak akkor szabad a mérlegbe felvenni, ha biztosított azok egyértelmú értékelése. Az értékalapú megközelítés alapvetô előnye, hogy egyrészt csökkenti a kevert áras eljárások által biztosított elszámolások eredménymegállapításra gyakorolt hatását, másrészt egyszerúsítheti a pénzügyi kimutatások értelmezhetôségét.

Az értékelésben a számvitellel kapcsolatos kihívások a világválságok következtében erósödnek fel, ezek közül elsősorban az infláció tette egyértelmúvé, hogy egy adott vagyonelemnek, attól függóen, hogy milyen szempontból nézzük, különféle értéke lehet (bekerülési, piaci, utánpótlási érték), és ez eltérő vagyonértékhez és eredményhez vezet. Az infláció hatása egyrészt az egyes eszközök és források bekerülési értékének meghatározásához, másrészt azok mérleg-fordulónapi értékeléséhez kapcsolódik, ahol figyelembe kell venni az összemérés és az óvatosság elvét is. A piaci érték meghatározása azonban nem mindig egyértelmú, mivel az egyes tételek mérlegben kimutatott értékének valódiságát számos tényezó befolyásolja. Ide tartozik a bekerülési érték, az év közben elszámolt állományváltozások értéke, az értékvesztések és a mérleg-fordulónapi értékelés. Ez utóbbi esetben az inflációhoz kapcsolódóan értékhelyesbítést lehet kimutatni, illetve a kimutatott értékhelyesbítést módosítani lehet. A piaci érték meghatározásánál a valós érték fogalmi kerete szolgálhat alapul. A számvitelben jelentkezô értékelési problémákra egyrészról a különféle mérlegelméletek, ${ }^{12}$ másrészról az értékalapú számvitel egyes területei (árváltozás, valós érték, értékvesztés) kísérelnek meg választ adni. Más megközelítésben a számviteli értékelés kihívásai a tôkemegtartási koncepciók fejlődésével jelentkeznek, mivel e koncepciók határozzák meg, hogy milyen számviteli modellt használnak, és annak mi az eredményhatása. Ez azt is jelentheti, hogy a pénzügyi kimutatásokban az értékkategóriák tisztázása és új tételek bevezetése is szükséges lehet. A pénzügyi 
válság ellenére a legtöbb pénzügyi instrumentum számára a valós értékelés a legrelevánsabb értékelési elv, bár a valós értékelés fellendülés idején túlzottan optimista, míg a pénzügyi válság során pesszimista értékeléshez vezet. Ennek ellenére Tardos (2009) szerint nem a valós értékelés okolható a válságok kialakulásáért, hiszen ez önmagában nem tekinthető torzító hatásúnak.

\section{Az értékalapú számvitel közgazdasági alapjai és a valós érték mérése}

Az értékalapú számvitel más és más tartalommal jelent meg az elmúlt időszakokban. Az első ilyen forma az árváltozás számvitele volt, ez leginkább a nem pénzügyi eszközök folyamatos árnövekedésével állt kapcsolatban, és az 1970-es éveket (magas inflációval jellemezhető idôszakokat) ölelte fel. Az értékalapú számvitel második változata a valós értékelés számvitele, amely az 1980-as évek közepén jelent meg, és napjainkban ennek legfontosabb területe a pénzügyi instrumentumok/származékos ügyletek elszámolása, ${ }^{13}$ amely a pénzügyi piacok kamat- és árváltozási kockázatának kitett eszközök számviteli problémáival foglalkozik. A harmadik forma az értékvesztés/értékromlás számvitele (,impairment accounting"), amely elsôsorban a jövedelmezőség csökkenése miatti vagyonvesztés elszámolásával foglalkozik (például a deflációs gazdaságokban). Fontos megjegyezni, hogy az értékalapú számvitel különböző változatai eltérő gazdasági és társadalmi feltételek mellett alakultak ki. A számviteli megközelítés változását és fókuszpontjait szemlélteti az 1. ábra.

Napjaink értékalapú számvitele alapvetően eltér az 1970-es évek árváltozási számvitelétôl, bár mindkettó egyfajta „piaci értéket” próbál megragadni, az eltérések azonosítása ugyanakkor segíthet abban, hogy hogyan definiáljuk a valósértékelés számvitelének jellegzetességeit. Másképpen fogalmazva, melyek az elsôsorban pénzügyi instrumentumokra koncentráló valós értékelés számvitelének közgazdasági alapjai, és azok miben térnek el az árváltozás számvitelétől? Napjaink valós értékelés számvitelének megértéséhez szükséges az ezzel összefüggó számviteli kérdések közötti kapcsolat bemutatása - mint például a költségallokálás, realizálás, tekintettel az értékpapírok gazdasági tartalmára és a hitelezési rendszer fejlődésére.

Ezek közül az egyik leglényegesebb, hogy a pénzügyi instrumentumok/származékos ügyletek valós értékelésének számvitelével összefüggó tốketípus a fiktív tốke, amelynek a gazdaságban való áramlása eltér a valós tốkétól, és ez azt jelenti, hogy a fiktív tớke természetéból adódóan az árazása is teljesen más, mint a fizikai javaké. Míg a fizikai tóke a hagyományos (funkcionális) javak átalakításával (M-C-M') áll kapcsolatban, addig a fiktív tốke áramlása a következô módon megy végbe: a részvényeket (S) a kibocsátás után értékesítik $(M)$, ennek az összegnek egy része $(\mathrm{m} 1)$ a kibocsátóé, a másik része (M1) átalakul produktív tốkévé. Amennyiben a részvényeket újra eladják, további pénzre (M2) van szükség. Ennek az áramlásnak (S-M2-S) a helye a tôzsde, és ezért nincs semmilyen közvetlen hatása a produktív tốkére. A valós és a fiktív tốke áramlását mutatja be a 2 ábra.

Amíg a hagyományos, költségekre és realizálásra koncentráló számviteli keret a fizikai tóke áramlását (ami gyakorlatilag termékek és szolgáltatások előállítását és értékesítését jelenti) volt hivatott rögzíteni, addig a fiktív tốke áramlásának nyomon követésére teljesen más számviteli keretre van szükség, tehát a korábbi fizikai tókére tervezett számviteli keretet nem lehet kiterjeszteni a fiktív tókével kapcsolatos elszámolási problémákra. Uno (1977) és Kimura (1972) szerint a piacgazdaság viszonyai között egy meghatározott pénzösszeg után járó kamatfizetés egy periodikus bevételsorozat azonosítására

1. ábra

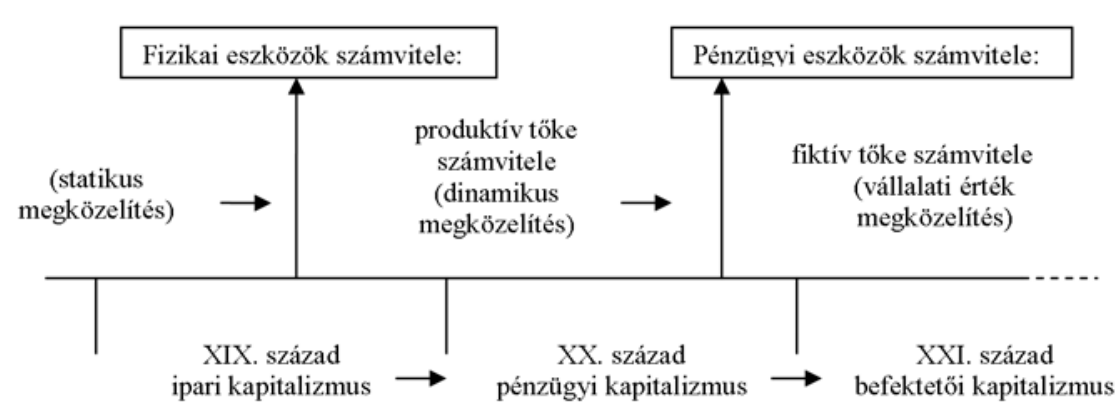

Forrás: Ishikawa (2005) p. 126.

\section{VEZETÉSTUDOMÁNY}


alkalmas, azaz e periodikus bevételeket kapitalizálhatjuk a pénzpiacon kialakult kamatrátával, és tekinthetjük az ún. fiktív tốke kamatának. Bár a fiktív tốkének sokféle meghatározása előfordul a szakirodalomban, leginkább abból kell kiindulni, hogy a fizikai eszközök és a tốke természete alapvetően elkülönül egymástól. A fizikai eszközök értékesítése, áruként történő kezelése során ugyan egy fiktív értéket kapnak, de a tôke önmagában nem fizikai eszközként vagy dologként határozható meg, hanem pénz-, illetve jövedelemszerzésre irányuló tevékenységként. A tốke csak valamilyen pénzügyi eszköz formájában kezelhetô értékesíthetô dologként, illetve fiktív tốkeként. Közgazdasági és számviteli szempontból azért fontos a különbségtétel, mert az értékpapírként megjelenő pénzügyi eszközök piaci ára, amely az osztalék és kamat átlagos kamatlábbal történő kapitalizálásából származtatható, teljesen eltér a költségalapú árképzéstől. Míg a javak vagy dolgok értéke és ára a termelés szociális kapcsolatain alapul, addig az értékpapírok ára a pénzpiacok tóketulajdon-viszonyaitól (általában különféle jogviszonyoktól) függ. A pénzügyi instrumentumokkal/ származékos ügyletekkel kapcsolatos számviteli problémák elsősorban a fiktív tốke elmúlt évtizedben bekövetkezett fejlődésének tudható be, amelyet az immateriális javak és üzleti kombinációk térnyerése is elősegített. Más értelemben a fiktív tóke kvalitatív és kvantitatív előretörését a kihasználatlan tốkére épülő hitelrendszer, illetve a jogi és intézményi rendszer fejlődése ösztönözte. Ezt a gondolatmenetet támasztja alá Hilferding (1981) is azzal, hogy a hitelrendszer kihasználatlan pénzt alakít át pénztốkévé különféle produktív tốkeelemek megvásárlásával. Ezen elméleti megfontolások lényegesek annak érdekében, hogy azonosítani tudjuk az ezen eszközökkel összefüggố aktuális számviteli problémákat, és betekintést nyerjük annak igazi természetébe. Mivel a fiktív tốke alapvető́n fiktív hiteltóke, és mivel a kockázatcsökkentố származékos ügyletek ennek egy magasabb szintjét képviselik, a meglévő számviteli keretek, vagy annak bizonyos kiterjesztései ezek azonosítására és mérésére nem lehetnek alkalmasak. Ezt indokolja az is, hogy az elmúlt harminc évben a kamat- és árváltozási kockázatnak kitett pénzügyi eszközök részaránya az összes vállalati eszközön belül jelentôsen növekedett, például az USA termelő vállalatainál ez az arány 44\% volt az 1990-es években, a 11\%-os 1960-as évekbelihez képest. A vállalatok tipikusan azért rendelkeznek eszközökkel, hogy növelni tudják a vállalat értékét. Ennek a célnak a megvalósítása során lényegtelen, hogy fizikai vagy pénzügyi eszközt használnak fel, csak abban az értelemben van különbség a két eszköztípussal kapcsolatban, hogy ki és hogyan teremt értéket, azaz az értékteremtésben különbözó szereplốk érintettek. A múködési eszközök általá- ban a vállalkozások termelési tevékenységében vesznek részt, így az érték lényegében a vállalat számára rendelkezésre álló munkaerô és management képességeitôl fog függeni, az eredményt pedig a realizált múködési bevétel és a múködési eszközök használati költségeinek (allokált költség) különbsége adja. Ezzel ellentétben a pénzügyi eszközök értékét nem a birtokosa, hanem annak végső felhasználója hozza létre. A pénzügyi eszközökkel rendelkező vállalkozásoknak fontos figyelemmel kísérniük befektetéseik hozamát, aktuális információk és piaci árak alapján meghatározva a valós értéket, ezzel lehetôség nyílik a management számára a pénzügyi eszközökkel való hatékonyabb gazdálkodásra. Az értékteremtés más módon megy végbe a múködési eszközök, és más módon a pénzügyi eszközök esetében. Az elóbbinél maga a vállalkozási tevékenység teremti az értéket, míg az utóbbinál a hozamokat és kockázatokat a piaci várakozások, makroökonómiai trendek és egyéb olyan tényezók alakítják, amelyek kívül esnek a vállalkozás ellenőrzési körén (Ishikawa, 2005).

A pénzügyi instrumentumok valós értéke alapvetően a piaci árból indul ki, de gyakran ezen árak nem tükrözik a reális értéket, mivel előfordulhat, hogy az adott eszköznek vagy kötelezettségnek nincs eléggé likvid másodlagos piaca. Ugyanakkor problémát jelenthet az is, hogy a számviteli beszámolókba beépül a piaci árak volatilitása is, amely nemcsak a vagyonérték, hanem a vállalkozás által kimutatott jövedelem változékonyságát is növeli. Ha ez a változás fundamentális okokra vezethetố vissza, az nem torzítja az adott vagyonelem valós értékét, ha azonban a piaci tökéletlenségból adódik a változás, ezt a piaci szereplók várakozásai is befolyásolják. Kevésbé likvid piacok esetén, egy nagyobb volumenú értékesítés során csökkennek az árak, és az eszköz értékelésekor az alacsonyabb piaci érték miatt a megtartása kevésbé kívánatos. A számviteli rendszer az ehhez hasonló, nem fundamentális áringadozások hatásait felerôsítheti. Előfordul olyan eset is, amikor a vállalkozások a piaci árak hiányában saját értékelési módszer alapján becsülik a valós értéket, ilyenek lehetnek például a különféle jelenérték-számítási modellek.

E módszerek azonban magukban hordozzák a becsléssel járó veszélyeket, úgymint a várható jövőbeli pénzáramlások és a kamatok előrejelzésével kapcsolatos bizonytalanságot. A becslések csak közelíteni tudják az elméleti valós értéket, mivel a becslések mindig szubjektívek, s ez így nem felel meg a nemzetközi és egyes országok számviteli standardjainak semlegességi követelményének. A valós értéknek - mivel az nem vállalkozásspecifikus - minden esetben a piaci szereplóik várakozásait kell tükröznie, de gyakran az adott eszköz, illetve kötelezettség értékében megjelennek a 
management által ismert olyan információk, amelyek előnyöket és hátrányokat is jelentenek, és amelyek még nem kerültek nyilvánosságra. A mérések megbízhatósága nagyban függ a management hozzáállásától, hiszen a saját várakozásai, szándékai befolyásolják az értékelést, ezek térben és időben is elkülönülhetnek, s ezáltal az összehasonlíthatóság követelménye sem teljesül. Ez bizonyos fokú szubjektivitást és megbízhatatlanságot eredményez, amely a mérési hibákon keresztül növelheti a pénzügyi instrumentumok vagy a vállalkozások értékének változékonyságát. A valós érték mérésének ugyanakkor az egyes eljárásoknak a piaci vagy a költség-, illetve jövedelemmegközelítésekkel összeegyeztethetőnek kell lennie.

A valós érték meghatározható hányadosalapú mutatószámokkal is, erre szolgál például a P/E (price/earnings) mutató. A jövedelemmegközelítés ugyanakkor az adott eszközzel kapcsolatos jövedelemáramlásokból indul ki, s ezek diszkontált értéke alapján állapítja meg a jelenlegi értéket. Ennek leggyakrabban használt formája a diszkontált cash flow-modell (DCF). A DCF-modell a vállalat saját tókéjének értékét a vállalati üzleti tevékenység értékének (a befektetők összességének rendelkezésére álló érték), valamint a hitelek és egyéb, a törzsrészvényeket megelőző követelések (például elsôbbségi részvények) értékének különbségeként határozza meg. A vállalati múködés üzleti értéke, illetve az adósság értéke megegyezik a hozzájuk tartozó pénzáramlásoknak az azok kockázatának megfelelő diszkontrátával diszkontált értékével (Kovács, 2007).

Európai viszonylatban a jövedelemalapú értékelés újszerú formájának számít az egyes eszközök vagy a vállalat egészének reálopciós értékelése. A számvitel szempontjából ennek a vállalati értékkel és teljesítménnyel összefüggố pénzügyi instrumentumok ${ }^{13}$ esetében van jelentôsége, melynek szerepe a bizonytalan piaci körülmények esetén még inkább felértékelődik. A módszer alkalmazásának hátterében a jelenérték-számítás kritikája húzódik meg, és a vállalati érték olyan opcióként való megadását foglalja magában, amelyek keretében egy jövôbeli, előre rögzített áron történő eladására kínálnak lehetőséget. A vállalati értéket és a tulajdonosok vagyoni helyzetét alapvetóen a kapott osztalék, illetve az árfolyamváltozás befolyásolja. Ezek a tényezók a vállalkozás jövedelemtermelő képességét tükrözik, ha ez megváltozik, akkor megváltozik a vállalkozás ára, illetve a részvényárfolyam is. Ez kétféleképpen is megközelíthetô, egyrészt a részvény által fizetett osztalékok jelenértékeként, másrészt a vállalat jelenlegi vagy jövoobeli beruházásainak jelenértékeként. A részvény által fizetett jövőbeli osztalékok és a növekedési lehetőségek becsléséhez a vállalkozás eszközeit két csoportra kell bontani: reáleszközökre és reál- opciókra. A reálopció egy eszköz kedvező körülmények között történő megszerzésére vonatkozó lehetőség, amely azt is jelenti, hogy a vállalatok értéke tükrözi a jövốbeli beruházási lehetôségekre vonatkozó várakozásokat is. A beruházások megvalósítása a jövốbeli idôpontban esedékes nettó jelenértékektôl függ. A vállalkozás értékének ez a része a jövốbeli üzleti lehetôségekre vonatkozó opciók jelenlegi értékétől függ, e növekedési lehetőségek a reáleszközökre vonatkozó vételi opciónak tekinthetók. A vállalkozások jövő́beli lehetôségeinek (kapacitásbővítés, új piacokra lépés) figyelembevételét a vételi opciók értékelésének módszerével lehet megoldani, bár ezek a módszerek egy-egy speciális helyzetre koncentrálnak, és nem veszik figyelembe a különböző opciós helyzetek egyidejú jelenlétét sem. A vállalati projektek reálopciók gyưjiteményeként értékelhetók, és a különféle opciók közötti kölcsönhatásokat is figyelembe kell venni. A vállalati gyakorlatban a reálopciós helyzeteket Trigeorgis (2001) alapján olyan csoportba sorolhatjuk, mint például a kibocsátás növelésére vagy csökkentésére, a múködés leállítására, vagy a vállalati növekedésre vonatkozó opciók. Az értékelés során valamennyi kapcsolódó opciós lehetôséget elemezni kell, mivel sokféle helyzet azonosítható opcióként, amelyekhez többféle értékelési eljárás kapcsolódhat ${ }^{14}$ (Andor - Bóta, 2006).

\section{A valós értékelés szabályozása és a válság hatása}

Nemzetközi szinten a valós értéken történő értékelést, mint az értékalapú számvitel részterületét, a pénzügyi instrumentumokkal foglalkozó nemzetközi számviteli standardok (IFRS 7, IAS 32, IAS 3915) szabályozzák. Ennek szükségességét az indokolta, hogy az elmúlt évtizedekben a pénzügyi világ jelentôs fejlődésen ment át, újabb és egyre bonyolultabb pénzügyi termékek, ügyletek, szolgáltatási ágazatok és az ezekkel kapcsolatos kockázatok jelentek meg, amelyekre a korábbi rendelkezések nem voltak felkészülve. Ezt támasztja alá néhány pénzügyi piac összeomlása (például 1997-1998-ban az ázsiai tôzsdeválság, az orosz és mexikói, illetve a 20072009-es pénzügyi válságok). A pénzügyi instrumentumok nemcsak a pénzügyi szektorban, hanem a gazdaság más vállalkozásaiban is elterjedtek. A magas likviditás és a könnyen elérhető befektetési lehetőségek egyrészt nagyobb mozgásteret, védelmet nyújtanak a befektetőnek, másrészt növelik az árváltozások valószínúségét, és ezáltal a hozamváltozás kockázatát. Ekkor viszonylag kismértékú várt árváltozás is nagy adásvételi szándékhoz vezet, és a keresett vagy kínált mennyiségek növekedése további árváltozásokat okoz. A pénzügyi piacok ilyen mértékú volatilitása azt eredményezte, hogy először kidolgozták a kockázat azonosításának, kezelésének el- 
méletét, majd az ezeket alkalmazó speciális kockázatkezelésre alkalmas derivatív termékeket és ügyleteket. E megváltozott körülmények miatt olyan szabályozás vált szükségessé, amely egyértelmúen meghatározza a pénzügyi instrumentumok fajtáit, azok kockázatainak számszerúsítését, kezelését és azok fedezését.

Az USA számviteli standardjai (US GAAP ${ }^{16}$ ) már korábban is szabályozták a pénzügyi instrumentumok elszámolását, emellett a nemzetközi számviteli standardtestület (IASB), illetve az Európai Unió is törekszik az IAS és a US GAAP összhangjának megteremtésére. ${ }^{17}$ Az IAS 32 és az IAS 39 standardok a pénzügyi instrumentumok egy részénél kötelezôvé vagy lehetővé tették a valós értéken történő értékelést, így a vállalatok bizonyos köre köteles azt alkalmazni, figyelembe véve, hogy biztosítani kell az egyedi éves beszámolóban és a konszolidált éves beszámolóban annak azonos módon való alkalmazását. A nemzetközi szabályozás e változásai tették szükségessé, hogy a magyar számviteli szabályokba is adaptálásra kerüljön a valós értéken történő értékelés ${ }^{18}$ (Pete, 1999; Nagy, 2004a).

Noha a valós értéken történó értékelésnek számos elő́nye van, számviteli alkalmazása bizonyos költségekkel is jár. Az egyik alapvető probléma, hogy a pénzügyi kimutatások egyes sorainak értéke hogyan mérhetó megbízhatóan, különösen azon eszközök esetében, amelyeknek nincs aktív piaca. Ilyen esetekben a befektetóknek és más döntéshozóknak kell megbecsülniük, hogy a számviteli információk mennyire hasznosnak, illetve a pénzügyi kimutatásokkal szemben támasztott minőségi jellemzóknek megfelelnek-e. A jellemzók pontos tartalmi ismerete mellett hangsúlyozni kell a közöttük lévő arányokat (trade-off), illetve azok érvényesítését és az ezzel járó költségeket. Ebból a szempontból a relevancia és a megbízhatóság a leglényegesebb (Landsman, 2006). Egy információ akkor tekinthetô relevánsnak, ha befolyásolják a gazdasági szereplő döntéseit, és akkor lehet hasznos, ha megbízható. Egy információ lehet releváns, miközben teljesen megbízhatatlan, és fordítva. Az információk hasznossága tehát e két jellemző megfelelő arányára épül. A gazdasági folyamatok és az üzleti környezet változásának függvényeként ez az egyensúlyi pont is állandóan változik. A számviteli szabályozásban a relevancia és a megbízhatóság közötti megfelelő arányra egyaránt figyelemmel kell lenni. E tekintetben a valós értéken történő értékelés megjelenése egy új relevancia-megbízhatóság arány kialakulását eredményezheti. Mindez alapvetően összefügg a beszámolási elvekkel, ugyanis a valós értéken történő értékelés elősegíti a számviteli információk hasznosságát, de a legutóbbi krízis bebizonyította, hogy továbbra is igény van a bekerülési értékek megjelenítésére. A valós érték jobban tükrözi a piacot, a piaci értékítéletet, de nagyobb változékonyságot eredményez a különféle vagyonelemekben és a jövedelmezőségben (Bosnyák, 2004).

2008 és 2009 folyamán számos változás és iránymutatás született az elmúlt idôszakban tapasztalható pénzügyi válság hatására a számviteli előírásokban. Az IAS 39 változásának lényege, hogy a társaságoknak lehetôségük nyílik arra, hogy a korábbiakban eredménynyel szemben valós értéken értékelt vagy értékesíthető kategóriában lévő, de a kölcsönöknek és követeléseknek megfelelő instrumentumokat átsorolják a kölcsönök és követelések kategóriába. A változás hatása az, hogy miközben az eredménnyel szemben valós értéken értékelt és az értékesíthető kategóriában lévő instrumentumokat valós értéken kell értékelni, addig a kölcsönök és követelések kategóriában lévő pénzügyi eszközöket (amortizált) bekerülési értéken kell bemutatni. Az IAS 39 szerint a vállalkozásoknak követniük kell az értékelési hierarchiát: elsố lépésként az aktív piacon lévő jegyzett árat kell alkalmazniuk, amennyiben ez rendelkezésre áll, ennek hiányában pedig belső modellekkel kell a valós értéket meghatározniuk.

A standardváltoztatás fố indoka, hogy mivel a válság előtt azonnal rendelkezésre állt a pénzügyi piacokról számos instrumentum valós értéke, sok vállalkozás besorolta pénzügyi instrumentumait az eredménnyel szemben valós értéken értékelt kategóriákba. A válság hatására azonban ezek az aktív pénzügyi piacok sokszor nem múködtek, és már nem álltak rendelkezésre a valós értékek. Az IAS 39 szerint ilyen esetben eddig nem volt lehetőség arra, hogy ezekból a kategóriákból átsoroljon instrumentumokat a vállalkozás. Az instrumentumok valós értékét pedig piaci árak hiányában belsố modellek segítségével kell meghatároznia a társaságnak, ugyanakkor a standard változása megköveteli, hogy az átsorolást megelőzően az instrumentumokat valós értékre értékeljék át. ${ }^{19}$

A valós érték meghatározásának problémája érinti mind a magyar, mind a bármilyen nemzetközi számviteli standardok alapján készítendő beszámolókat. A valós érték megállapítása befolyásolja többek között a hitelviszonyt megtestesító értékpapírok, részvények, részesedések, származékos ügyletek, üzleti kombinációk, befektetési célú ingatlanok és a kiegészítő megjegyzésekben vagy kiegészítő mellékletben megjelenő közzétételeket. E területeken a legjelentősebb problémát az jelenti, hogy több instrumentum korábban létezô aktív piaca megszúnt, és így már nem áll rendelkezésre piaci ár. 2008 októberében az IASB oktatási iránymutatást (educational guidance) adott ki a pénzügyi instrumentumok valós értékének mérésére. A likvid piacok hiánya miatt a vállalkozások számára szükségessé válik értékelési modellek kidolgozása, ám gyakran nem áll rendelkezésre a szük- 
séges szakmai tudás és tapasztalat a modellek kialakításához. További problémát jelent, hogy e módszerekre vonatkozó útmutatások a nemzetközi számviteli standardokban elosztva találhatók, és nem mindig következetesek. Az IASB célja, hogy létrehozzon egy standardot, amely egyértelmúvé teszi a valós érték mérését, ezért 2009 májusában megjelentetett egy ezzel kapcsolatos tervezetet (exposure draft, ED). A döntést az indokolja, hogy a jelenlegi standard (IAS 39) - az elszámolásokat tekintve is - összetett, és nem mindig eredményezi a leghasznosabb információt, ezért 2008 márciusában kiadtak egy vitaanyagot a pénzügyi instrumentumok jelentésének egyszerúsítésére (IASB, 2008a, 2008b, 2009a, 2009b). A valós értékelés egyik legproblémásabb területe a fedezeti elszámolásokkal kapcsolatos. A cash flow-fedezeti ügyletek esetében az üzleti környezet negatív változásainak hatására (mint például megszúnő megrendelések, nem fizetô vevốk, cső́dbe jutott partnerek) jelentôsen csökkent a jövốbeni pénzáramlások valószínúsége. Az értékvesztés területe - a tevékenység jellegétól függetlenül - szinte minden vállalkozást érint. Az ezzel kapcsolatos probléma kiterjed a pénzügyi instrumentumokra, azaz az értékpapírokra, hitelkövetelésekre, vevókövetelésekre, származékos ügyletekból eredő követelésekre, de érinthet más eszközöket is, mint például a tárgyi eszközöket, immateriális javakat, halasztott adóeszközöket. $\mathrm{Az}$ értékvesztés elszámolásánál a legfontosabb kérdés, hogy várható-e a könyv szerinti érték megtérülése, és milyen mértékben. A várható megtérüléseket leginkább az adósok várható fizetốképessége (a vevốköveteléseknél), illetve az eszközök múködtetéséből várható jövőbeni pénzáramlások befolyásolják.

A pénzügyi válságban a cégek tevékenységi körüktôl függő̂en eltérô módon érintettek, de szinte minden vállalkozás esetében igaz, hogy nem lehet mérlegelés nélkül elfogadni a múltbeli statisztikákon és tapasztalatokon alapuló értékvesztésképzést. Az értékvesztéshez hasonló problémák merülnek fel a céltartalékképzés során is, itt leginkább a nem fedezeti célú származékos ügyletek után képzendő céltartaléknál a valós érték meghatározása okoz nehézséget (Fekete, 2009; Boros Rakó, 2009).

\section{Összegzés}

Az elmúlt évtizedekben a globalizálódó világgazdaság, az információs technológia fejlődése, a tranzakciós költségek csökkenése és a pénzügyi piacok fejlődése miatt a vállalatok egyes vagyonelemeivel kapcsolatban a hangsúly a piaci értékre helyeződött. Mivel döntéseik meghozatalához a pénzügyi beszámolók adatait használják fel, a piaci szereplók igényei nagyban befolyásolják a szám- viteli rendszerek információtartalmát. A finanszírozás elméleti és gyakorlati módszereinek kiszélesedése egymást kölcsönösen erősító módon zajlott, és ezzel egyidejúleg a globalizáció újabb és újabb kihívásokat támasztott a számvitelben. A vállalkozások megnövekedett kockázatainak kezelésére az új módszerek vagy tranzakciótípusok megoldást jelenthetnek, ám a különféle származékos ügyletek széles körû elterjedése veszélyeket is magában hordoz. A lezajló változások és egyéb olyan tényezók, mint a tranzakciós költségek alacsony volta, egyes pénzügyi piacokon az árak növekvố volatilitásához és fokozott instabilitáshoz vagy spekulációhoz vezethet. A közelmúlt tapasztalatai alapján megállapítható, hogy a pénzügyi instrumentumok vállalkozásoknál betöltött egyre fontosabb szerepe és a világgazdasági krízis miatt célszerú a vállalkozások számára olyan értékalapú számviteli rendszert kialakítani, amely a hatékonyabb döntéshozatalt segíti eló. Ez az újszerú számviteli megközelítés ugyan előtérbe helyezi a valós értéken történő értékelést, de a válság miatt ennek széles körú kiterjesztése az öszszes pénzügyi eszközre, illetve egyéb mérlegtételekre az elkövetkezô idôszakban nem várható. A jövớben a vállalkozások számára lényeges, hogy az eltéró gazdasági tartalmú jövedelmek meghatározására és mérésére megfelelő számviteli keretet használjanak, mivel a különböző elszámolási rendszerek és értékelési szabályok kérdésessé teszik az egyes pénzügyi beszámolók összehasonlíthatóságát. A standardalkotó testületek tevékenységének alapvetően arra kell irányulnia, hogy feltárják a globális válságból eredô pénzügyi beszámolási problémákat, lehetôvé téve a beszámolók felhasználói számára, hogy egy jól hasznosítható és reális képet kapjanak a vállalkozások üzleti teljesítményéról.

\section{Lábjegyzet}

${ }^{1}$ International Valuation Standards Committee

${ }^{2}$ International Accounting Standards, International Financial Reporting Standards

3 International Valuation Standards

${ }^{4}$ A nemzetközi értékelési standardok a következő számviteli standardok értékelési előírásait pontosítják (IASB [2007]): IAS 1 Bevezetés, IAS 16 Termelési célú tárgyi eszközök, IAS 17 Lízing, IAS 40 Befektetési célú tárgyi eszközök, IAS 36 Értékvesztések, IAS 2 Készletek, IFRS 5 Megszúnő tevékenység, IFRS 3 Konszolidáció, IAS 41 Mezőgazdaság.

${ }^{5}$ Bár a szakirodalomban sokféle meghatározás létezik, pénzügyi instrumentum az olyan szerződéses megállapodás, amelynek következtében az egyik félnél pénzügyi eszköz, a másiknál pénzügyi kötelezettség vagy tôkeinstrumentum keletkezik. Ide tartoznak a különféle pénzeszközök, szerződéses követelések és kötelezettségek, értékpapírok és a származékos ügyletek.

${ }^{6}$ A pénzpiacok és a pénzügyi intézmények fejlődésérôl, azok megváltozott szerepéról, valamint a pénzügyi innovációról az információs gazdaságban részletesen ír Merton (1995). 
${ }^{7}$ Financial Accounting Standards Board

${ }^{8}$ International Accounting Standards Board

${ }^{9}$ Securities and Exchange Commission

${ }^{10}$ A magyar számviteli törvény szerint eszközök vagy kötelezettségek valós értékét becslés alapján kell megállapítani, amely a vállalkozás folytatásának elvét követi.

${ }^{11}$ Erról részletesebben lásd (Baricz, 1994).

${ }^{12}$ Ezt nevezik a befektetések értékalapú számvitelének is.

${ }^{13}$ Például a tulajdonosi részesedést jelentő befektetések vagy különféle hitelviszonyt megtestesító értékpapírok.

${ }^{14}$ A módszerek között a különbséget a bizonytalanság forrásának azonosítása jelenti, ezek lehetnek a költségek, a kamatlábak, illetve a reálárfolyam alakulására döntéseket építő modellek.

${ }^{15}$ IFRS 7 Pénzügyi instrumentumok: Közzététel, IAS 32 Pénzügyi instrumentumok: Bemutatás, IAS 39 Pénzügyi instrumentumok: Megjelenítés és Értékelés (IASB, 2007).

${ }^{16}$ United States Generally Accepted Accounting Principles

${ }^{17}$ 2001/65/EK irányelv, amely módosította az éves beszámolóra vonatkozó korábbi 78/660/EGK/ 4. számú, valamint a 83/349/EGK 7. számú és a 86/653/EGK irányelveket az értékelésben.

${ }^{18}$ A számvitelról szóló 2000. évi C. törvény, illetve a hitelintézetek és pénzügyi vállalkozások éves beszámolókészítési és könyvvezetési kötelezettségeinek sajátosságairól szóló 250/2000. (XII. 24.) kormányrendelet.

${ }^{20}$ Az Európai Unió az 1725/2003/EK-rendeletének módosításával a módosítást befogadta, a magyar számviteli törvény 2008. december 10-i hatállyal változott.

\section{Felhasznált irodalom}

Andor Gy. - Bóta G. (2006): Üzletértékelés reálopciós módszerrel, Számvitel Adó Könyvvizsgálat, december, p. 535-538.

Baricz R. (1994): Mérlegtan, Aula Kiadó, Budapest

Baricz R. (2008): A számvitel súlypontjai, Számvitel Adó Könyvvizsgálat, jubileumi melléklet, p. 3-6.

Bordáné Rabóczki M. (1990): A gazdasági társaságok pénzügyi megítélése, Közgazdasági és Jogi Könyvkiadó, Bp.

Boros J. - Rakó Á. (2009): A pénzügyi válság hatása az év végi beszámolók összeállítására és a könyvvizsgálatokra, Számvitel Adó Könyvvizsgálat, január, p. 14-18.

Bosnyák J. (2004): Valós értékelés a magyar és nemzetközi szabályozásban, Számvitel Adó Könyvvizsgálat, október, p. 435-439.

Deák I. (2008): A számvitel vagyonfelfogásáról, Számvitel Adó Könyvvizsgálat, december, p. 497-505.

Fekete I.-né (2009): A globális válság szakmai kihívásai, Számvitel Adó Könyvvizsgálat, január, p. 20-24.

Havas I. (2002): Értékfajták, értékelési standardok a vállalkozások értékelésében, elemzésében, Számvitel Adó Könyvvizsgálat, szeptember, p. 385-391.

Hilferding, R. (1981): Finance capital: a study of the latest phase of capitalist development, Routledge \& Kegan Paul, London

IASB (2007): Nemzetközi Pénzügyi Beszámolási Standardok (IFRS-ek) 2006, beleértve a Nemzetközi Számviteli Standardokat (IAS-ek) és az Értelmezéseket 2006. január 1-jén, IASCF, London

IASB (2008a): Improving Disclosures about Financial Instruments (exposure draft), IASC, London
IASB (2008b): Proposals on changes to the disclosures about investments in debt instruments, IASC, London

IASB (2009a): Fair Value Measurement (exposure draft), IASC, London

IASB (2009b) Derecognition, Proposed amendments to IAS 39 and IFRS 7 (exposure draft), IASC, London

Ishikawa, J. (2005): A social science of contemporary valuebased accounting: economic foundations of accounting for financial instruments, Critical Perspective on Accounting, Volume 16, Issue 2, February, p. 115-136.

Jakab Á. - Matukovics G. - Ormos M. (2006): A vagyon- és üzletértékelési standardok bevezetésének egyes kérdései Magyarországon, SzámAdó, április, p. 7-9.

Kimura, W. (1972): Accounting studies as a social science, Yuhikaku, Tokyo

Korom E. - Ormos M. - Veress A. (2005): Bevezetés a számvitel rendszerébe, Szemlélet és módszertan, Akadémia Kiadó, Budapest

Kovács D. M. (2007): A valós érték mérésének problémái és az amerikai válasz, SzámAdó, 5. szám, p. 7-13.

Landsman, W.R. (2006): Fair Value and Value Relevance: What Do We Know?, Kenan-Flagler Business School, University of North Carolina, november, Information for Better Markets Conference, sponsored by the Institute of Chartered Accountants of England and Wales, 2006. december 18-19.

Merton, R.C. (1995): Financial innovation and the management and regulation of financial institutions, Journal of Banking \& Finance 19, p. 461-481.

Nagy K. (2004a): A valós értéken történő értékelés I. rész, Számvitel Adó Könyvvizsgálat, április, p. 149-153.

Nagy K. (2004b): A valós értéken történő értékelés II. rész, Számvitel Adó Könyvvizsgálat, május, p. 203-207.

Pete P. (1999): Gondolatok a ,pénzvilág uralmáról”, a pénzügyi rendszer megnövekedett szerepéről, Közgazdasági Szemle, XLVI. évf., május p. 389-402.

Tardos Á. (2009): Pénzügyi válság, valós értékelés, hitelek értékvesztése, Számvitel Adó Könyvvizsgálat, jún., p. 262-264.

Trigeorgis, L. (2001): Real options: An Overview, In: Schwartz, E. S. - Trigeorgis, L. (szerk.) [2001]: Real Options and Investment under Uncertainty, MIT Press

Uno, K. (1977): Principles of political economy: theory of a purely capitalist society, Harvester Press

Wilson, A.C. - Stanwick, S.D. (1995): Concerns with and alternatives to current accounting for derivative instruments, The CPA Journal, December, p. 50-51.

Zboray I. (2009): Az IASB válasza a globális pénzügyi válságra, Számvitel Adó Könyvvizsgálat, július-augusztus, p. 329-331.

Zékány A. (2006): A számvitel a tôzsde világában, Számvitel Adó Könyvvizsgálat, szeptember, p. 379-384.

2000. évi C. törvény a számvitelról

Cikk beérkezett: 2009. 3. hó

Lektori vélemény alapján véglegesítve: 2009. 8. hó 